RESEARCH ARTICLE

\title{
Does over-dominance of Bambusa bambos (L.) Voss. alter abundance and richness of Arbuscular Mycorrhizal fungal community in forests?
}

\author{
Fathima Mafaziya ${ }^{1}$, Tharanga Wijewickrama² and H.M.S.P. Madawala ${ }^{3, *}$
}

\author{
${ }^{1}$ Department of Biological Sciences, South Eastern University of Sri Lanka, Sammanthurai, Sri Lanka \\ ${ }^{2}$ Postgraduate Institute of Science, University of Peradeniya, Peradeniya, Sri Lanka \\ ${ }^{3}$ Department of Botany, University of Peradeniya, Sri Lanka
}

Received: 11/06/2018; Accepted: 19/09/2018

\begin{abstract}
Tropical Moist Evergreen forests (TMEF) are the major forest type in the Intermediate Climatic Zone of Sri Lanka. Some of these forests are heavily dominated by a native bamboo species, Bambusa bambos (L.) Voss. altering the hierarchical status and structure. The study evaluated whether the over-abundance of $B$. bambos has modified the arbuscular mycorrhizal fungal (AMF) communities in soil. Soil samples collected from bamboo-dominated (BM) and non-bamboo (NB) forest patches in three different locations viz., Moragolla, Maragomuwa and Galboda, were enumerated forAMF spores using wet sieving and decanting method. A total of 1,577 and 898 AMF spores were documented from BM and NB forest patches, respectively. A total of 14 different morphotypes belonged to the genera, Glomus, Scutellospora, Gigaspora and Acaulospora, were identified. Glomus was the dominant genus in all study sites, while Acaulospora the least. The mean abundance and richness of AMF spores were higher in BM than in NB, with the most notable difference observed at Maragomuwa. The site-specific variations may perhaps due to the differences in vegetation characteristics, edaphic properties and disturbance regimes. However, the community structure of AMF showed no conspicuous modifications due to the over-abundance of $B$. bambos. The findings reiterated the general understanding that any changes to the above-ground vegetation may incur impacts on the AMF. However, AMF community structure shows resilience to influences imposed by the dominance of a single species.
\end{abstract}

Keywords: Over-dominance, Bambusa bambos, arbuscular mucorrhizal fungi, Tropical Moist Evergreen Forests, Sri Lanka.

\section{INTRODUCTION}

In recent years, soil microbial communities and their participation in ecosystem functions received renewed interests from scientists. Studies confirm a closer link between the above- and below-ground communities, thus any alterations to the vegetation may incur significant changes to the soil microbial community (Grayston et al., 2004; Sun et al., 2016). Invasion by exotic plants is considered as the one of the main contributory factors to bring about changes in vegetation (McDowell and Allen, 2015). The invasion-driven changes to the vegetation have in turn altered the below-ground parameters including the soil microbiota (Vila et al., 2011; Rodriguez et al., 2015; Yang et al., 2016), perhaps through changes in litter quality and quantity, soil moisture and temperature, root exudates and nutrient turnover rates (Ehrenfeld, 2010). The studies show that the invasion of exotic bamboos sustain significant impacts on the structure and diversity of soil microbial communities, with more emphasis on bacteria (Chang and Chiu, 2015; Lin et al., 2014) than that of fungi (Xu et al., 2015; Li et al., 2017). Of the many fungal groups present in soil, Arbuscular mycorrhizal fungi (AMF) play a vital role in maintaining the composition and diversity of natural and semi-natural ecosystems. AMF show facilitative effect on the invasion success of some exotic plants (Edirisinghe and Madawala, 2017) while others show that AMF could transform habitats to resist invasion (Yang et al., 2016; Zhang et al., 2010), through positive/negative plant-AMF feedback.

In the recent past, scientists have noted that even some native species display an ability to expand their populations, altering the dominance hierarchies of resident forests (Larpkern et al., 2011). Based on the relatively known impacts of exotic plant invasions, it is correct to assume that over-abundance of native plants may also incur similar influences on the soil microbiota, especially when the focal species show properties in contrast to the previously dominant species. Population expansion of moso bamboo (Phyllostachys pubescens) in broad-leaved native forests in China has markedly declined the richness and diversity of the vegetation while inducing shifts in the soil fungal community further corroborating the intimate link between the soil fungi and vegetation (Bai et al., 2013; Peay et al., 2013; Chang and Chiu, 2015; Qin et al., 2017).

Bambusa bambos, a native bamboo species, expands populations in some parts of their resident forests in Intermediate and Dry Climatic Zones of Sri Lanka, altering the structure and composition of forest communities. Due to its thorny nature, the economic value of $B$. bambosis relatively low in comparison to other bamboo species present in the island. Until now, few studies have been undertaken to explore the immediate impacts on the above- 
and below-ground communities following the dominance of $B$. bambos in native forests in Sri Lanka (Wijewickrama et al., 2017). The current study investigated whether the over-dominance of B. bambos has the potential to alter the abundance, composition and richness of AMF communities in these native forests.

\section{MATERIALS AND METHODS}

\section{Site Description}

The study was carried out at Moragahakanda area in the Central Province of Sri Lanka. Lately, Moragahakanda experienced major land use changes due to the construction of a dam across the river Amban, one of the main tributaries of the river Mahaweli, for irrigation and power generation purposes. The area is under the Intermediate Climatic Zone and IM3 Agroecological Zone. Tropical Moist Evergreen Forest (TMEF) is the most prevalent forest type in the area, with Mangifera zeylanica, Canarium zeylanicum, Filicium decipiens, Dimorcarpuslongan, Nothopegia beddomei and Gironniera parvifolia as dominant species (Gunatilleke et al., 2008). The mature forests have more or less a continuous canopy with relatively sparse ground vegetation. The altitude is approximately $200 \mathrm{~m}$ above sea level. The topography of the area, shaped by the Knuckles Mountain

Table 1: Basic soil characteristics at bamboo-dominated (BM) and non-bamboo (NB) forest patches in Galboda, Maragomuwa and Moragolla sites, Sri Lanka.

\begin{tabular}{lcccccc}
\hline & \multicolumn{6}{c}{ Study Sites } \\
\cline { 2 - 7 } & \multicolumn{2}{c}{ Galboda } & \multicolumn{2}{c}{ Maragomuwa } & \multicolumn{2}{c}{ Moragolla } \\
\cline { 2 - 7 } & BM & NB & BM & NB & BM & NB \\
\hline Maximum Canopy height (m) & 15 & 20 & 12 & 12 & 15 & 20 \\
Stem Density (per ha) & 2,744 & 2,955 & 5,106 & 4,494 & 1,866 & 2,606 \\
\hline "Soil Mineral Fractions (\%) & & & & & & \\
Sand & 40 & 38 & 33 & 32 & 37 & 40 \\
Silt & 33 & 41 & 37 & 49 & 37 & 35 \\
Clay & 25 & 21 & 28 & 19 & 26 & 24 \\
\hline "Soil pH & $6.1^{\text {bc }}$ & $5.9^{\text {bc }}$ & $6.3^{\text {ab }}$ & $6.2^{\text {ab }}$ & $6.5^{\text {a }}$ & $5.9^{\text {c }}$ \\
"Soil Moisture (\%) & 15.0 & 18.0 & 20.1 & 25.0 & 12.4 & 13.6 \\
\hline
\end{tabular}

\#Soil parameters were statistically analyzed using General Linear Model (GLM) and significant differences were only indicated usingdifferent upper case letters. GLM: Mineral Fractions: $F=0.01, p=0.913$; Soil pH: F = 19.35, p $\leq 0.000$; Soil Moisture (\%): F= $2.67, \mathrm{p}=0.108$.

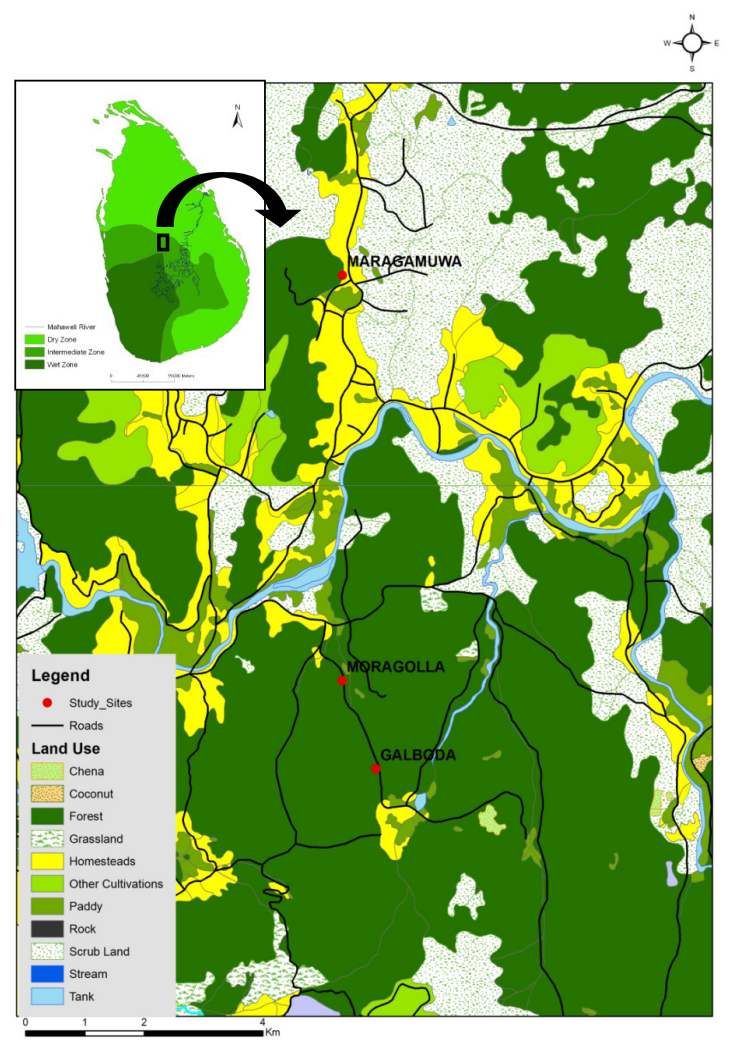

Figure 1: A land use map showing the three study sites (Moragolla, Maragomuwa and Galboda) located at Moragahakanda area close to the northern boundaries of the Intermediate Zone of Sri Lanka. 
Range, is classified as flat to gentle slopes (IUCN 2007). The mean annual rainfall is ranged from 1,750 to 2,500 $\mathrm{mm}$. The area receives rainfall from both north-eastern and south-western monsoons, with the bulk receiving from the latter. A short and less prominent dry season is experienced in the middle of the year. The mean annual temperature is ranged between $22.5^{\circ}-25.0^{\circ} \mathrm{C}$. The geology of the area is belonged to the Highland Series from the pre Cambrian era with reddish brown earths and immature brown loams as the major soil types (Somasekaram 1988).

Three representative TMEF forest patches, situated approximately $2-6 \mathrm{~km}$ apart and more or less equally dominated by bamboo (BM), were selected for the study viz., Galboda (GAL), Moragolla (MOR) and Maragomuwa (MAR) (Figure 1). Three comparable forest patches devoid of bamboo, hereafter will be known as non-bamboo (NB) forest patches, located close to their corresponding $\mathrm{BM}$ patches were also selected for comparison. The stand characteristics and some basic soil prameters of the study sitesare given in Table 1. Bambusa bambos (Poaceae) dominated in BM forests while Dimocarpus longan (Sapindaceae) was in NB forest patches.

\section{Sampling, extraction and identification of AMF spores}

Soil samples were collected from the top soil layer $(0$ - 10 $\mathrm{cm}$ ) from each study site using a spade at the end of a wet period during April and May, 2017. The $0-10 \mathrm{~cm}$ soil layer generally records the highest number of AMF spores compared to layers deeper down (Shukla et al., 2013). Each soil sample is a composite of three sub-samples taken from an area of approximately $1 \mathrm{~m}$ radius. From each BM and NB sites, 10 such composite soil samples were collected, totaling 60 samples in all study sites. The soil samples were kept in sealed and labeled polythene bags and stored in a refrigerator $\left(\right.$ at $\left.4{ }^{\circ} \mathrm{C}\right)$ until further analysis. From each sample, $100 \mathrm{~g}$ of soil was used to extract AMF spores using the wet sieving and decanting method, followed by sucrose centrifugation using a set of sieves of different mesh sizes viz., 125, 63 and $45 \mu \mathrm{m}$ (Sieverding, 1991). The spores were counted and identified into different morphotypes under $100-400 \times$ magnification using a stereomicroscope. The representative spores from each morphotype were mounted on slides using alcohol lacto-glycerol (PVLG) and identified to their generic level using spore characteristics given in INVAM website (http://invam.caf.wvu.edu). The spore density is the number of spores in $100 \mathrm{~g}$ of fresh soil. The species richness (number of spore morphotypes in $100 \mathrm{~g}$ fresh soil), relative abundance [(total number AMF spores belonging to each genera or spore size category/ total number of spores) $\times 100]$ and Shannon-Wiener Diversity Index $\left(\mathrm{H}^{\prime}\right)$ were also calculated. The mean abundance (average number of spores per $100 \mathrm{~g}$ fresh soil) and richness (average number of different morphotypes per $100 \mathrm{~g}$ fresh soil) of AMF spores were also determined.

Though conventional methods of enumeration and identification of AMF spores are known to be subjective, time-consuming and laborious, the recent published work provesthat these conventional methods are still been widely used by the scientists for their simplicity and reliability (Zhang et al., 2016; Willis et al., 2016; Zubek et al., 2016).
Sharma and Buyer (2015) compared conventional methods (wet sieving followed by microscopic observation) with that of lipid biomarker analyses and produced comparable results, further endorsing the validity of these methods.

\section{Statistical Analysis}

The General Linear Model (ANOVA:GLM) was performed to determine any significant effects of locations, dominance status (bamboo-dominated/non-bamboo), spore size $(125,63$ and $45 \mu \mathrm{m})$ and their respective interactions on the density and richness of AMF spores. Before using ANOVA, the data set is checked for normality of distribution. Mean separations were done using Tukey HSD at alpha $=0.05$. Soil parameters (soil moisture, soil $\mathrm{pH}$ and mineral fractions) were also analyzed statistically using GLM. All analysis was performed using Minitab 16.0 statistical software.

\section{RESULTS}

The wet sieving has yielded 1,577 and 898 AMF apparently live spores in BM and NB sites, respectively. Moragolla has recorded the highest number of AMF spores (964) followed by Maragomuwa (797) and Galboda (714). In all three study sites, bamboo-dominated (BM) forest patches recorded comparatively higher abundance of AMF spores in comparison to non-bamboo (NB) forests (Table 1). Of the totals (1,577 and 898), 36, 34 and $30 \%$ and 33, 30 and $37 \%$, of spores were categorized into 125,63 and 45 $\mu$ mspore size categories, in BM and NBrespectively. A total of 14 morphotypes of AMF spores were recorded in all study sites, belonging to four families, Glomeraceae, Scutellosporaceae, Gigasporaceae and Acaulosporaceae. Nearly half of the AMF spores were belonged to the family of Glomeraceae in both BM (45\%) and NB (50 $\%)$ forests, while the lowest contribution was recorded from Acaulosporaceae (7.5 and 6.6\% in $\mathrm{BM}$ and $\mathrm{NB}$, respectively).

Of the 14 morphotypes, three morphotypes were belonged to the genera Acaulospora and Scutellospora each and four morphotypes from Gigaspora and Glomus each. The diversity indices showed comparatively higher values in BM over NB forest patches in all study sites, except at Maragomuwa. The evenness values close to 1.0 indicate that AMF spores are distributed more or less evenly in all study sites, irrespective of the presence or absence of bamboo. 
Table 2: Abundance, richness, S-W Diversity and evenness indices of bamboo-dominated (BM) and non-bamboo (NB) forest patches at Moragolla, Maragomuwa and Galboda sites, Sri Lanka.

\begin{tabular}{|c|c|c|c|c|c|}
\hline \multicolumn{2}{|c|}{ Study Site } & $\begin{array}{l}\text { Total number of } \\
\text { AMF spores } \\
\text { (per kg soil) }\end{array}$ & $\begin{array}{c}\text { Total Number of } \\
\text { morphotypes } \\
\text { (per kg soil) }\end{array}$ & $\begin{array}{c}\text { Shannon-Wiener } \\
\text { Diversity Index } \\
\text { (H') }\end{array}$ & Evenness \\
\hline \multicolumn{6}{|l|}{ Moragolla } \\
\hline \multicolumn{2}{|l|}{ BM } & 563 & 12 & 2.250 & 0.905 \\
\hline \multicolumn{2}{|l|}{ NB } & 401 & 12 & 2.204 & 0.887 \\
\hline \multicolumn{6}{|c|}{ Maragomuwa } \\
\hline \multicolumn{2}{|c|}{$\mathrm{BM}$} & 602 & 12 & 2.201 & 0.886 \\
\hline NB & & 195 & 12 & 2.205 & 0.887 \\
\hline \multicolumn{6}{|l|}{ Galboda } \\
\hline \multicolumn{2}{|l|}{ BM } & 412 & 14 & 2.446 & 0.927 \\
\hline \multicolumn{2}{|l|}{ NB } & 302 & 14 & 2.353 & 0.892 \\
\hline \multirow{2}{*}{$\stackrel{\substack{: \\
\frac{n}{2}}}{\bar{z}}$} & NB & 32.8 & 30.3 & 369 & \multirow{9}{*}{$\begin{array}{l}\square 125 \mu \mathrm{m} \\
\square 63 \mu \mathrm{m} \\
\square 45 \mu \mathrm{m}\end{array}$} \\
\hline & $\mathrm{BM}$ & 35.8 & 34.1 & 301 & \\
\hline \multirow{2}{*}{$\begin{array}{l}\text { 퐁 } \\
\text { 过 } \\
\text { J }\end{array}$} & NB & 34.1 & 31.1 & 348 & \\
\hline & $\mathrm{BM}$ & 23.3 & 37.9 & 38. & \\
\hline \multirow{2}{*}{ 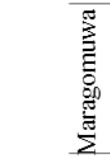 } & NB & 29.2 & 25.6 & 451 & \\
\hline & $\mathrm{BM}$ & 39.0 & 30.1 & 309 & \\
\hline \multirow{3}{*}{$\begin{array}{l}\frac{\pi}{0} \\
\overline{0} \\
\frac{0}{\tilde{I}} \\
\Sigma \\
\Sigma\end{array}$} & NB & 33.7 & 31.9 & 344 & \\
\hline & $\mathrm{BM}$ & 41.6 & 35.5 & 229 & \\
\hline & & $\begin{array}{l}20 \\
\text { Relative Abun }\end{array}$ & $\begin{array}{l}40 \\
20 \\
\text { of } \mathrm{AMF} \text { spores (as a }\end{array}$ & $\begin{array}{c}80 \\
\text { rom the total) }\end{array}$ & \\
\hline
\end{tabular}

Figure 2: Relative abundance of AMF spores (as a percentage from the total number of spores) classified under different size categories $(125,63$ and $45 \mu \mathrm{m})$ in bamboo-dominated (BM) and non-bamboo (NB) forest patches in Moragolla, Maragomuwa and Galboda sites, Sri Lanka.

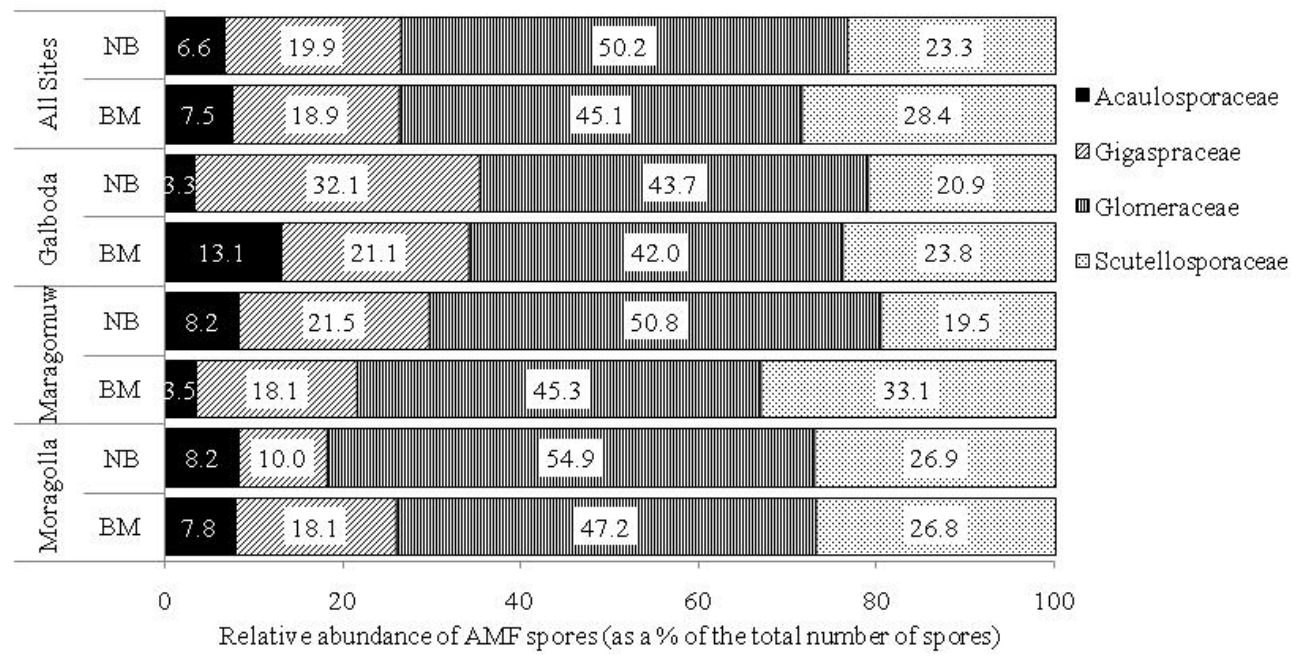

Figure 3: Relative abundance of AMF spores (as a percentage from the total number of spores) classified under different families in bamboo-dominated (BM) and non-bamboo (NB) forest patches in Moragolla, Maragomuwa and Galboda sites, Sri Lanka. 
The relative abundances (RA) of AMF spores belonging to three size categories and four genera were more or less similar between study sites irrespective of bamboo overdominance (Figures 2 and 3). In all forest patches, the family Glomeraceae recorded a higher RA of spores (42 $-55 \%$ ), followed by Scutellosporaceae and Gigasporaceae (Figure 3). The lowest contribution of AMF spores was reported from the family Acaulosporaceae $(3-13 \%)$. However, no distinct patterns were observed in RAs between BM and NB forest patches. In all study sites, 3 - 4 morphotypes, mainly of the genus Glomus, have contributed to $50 \%$ of the total RA, further highlighting the dominance of Glomus.

The mean abundance of AMF spores was significantly higher in BM forest patches in comparison to NB in both Maragomuwa and Moragolla sites, with a more striking difference in the latter (GLM: $\mathrm{F}=24.15, \mathrm{p} \leq 0.001$; Figure 4). The BM forests at Maragomuwa also demonstrated a significantly higher AMF spore richness in comparison to NB forest patch (GLM: F =9.16, p=0.004), with no such difference reported in other two sites.
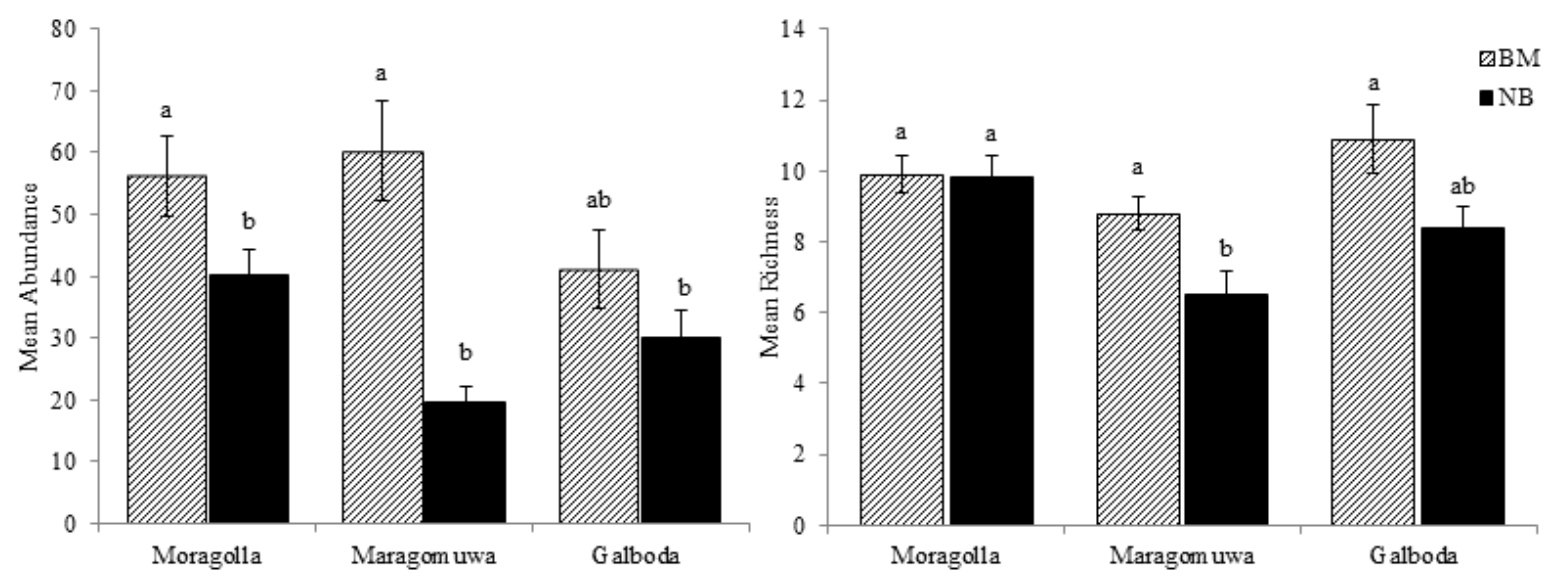

Figure 4: Mean abundance and richness of AMF spores (per $100 \mathrm{~g}$ fresh soils) in bamboo-dominated (BM) and non-bamboo (NB) forest patches in Moragolla, Maragomuwa and Galboda sites, Sri Lanka. Significant differences are indicated using different lowercase letters. Vertical bars represent standard error of means (SEM).

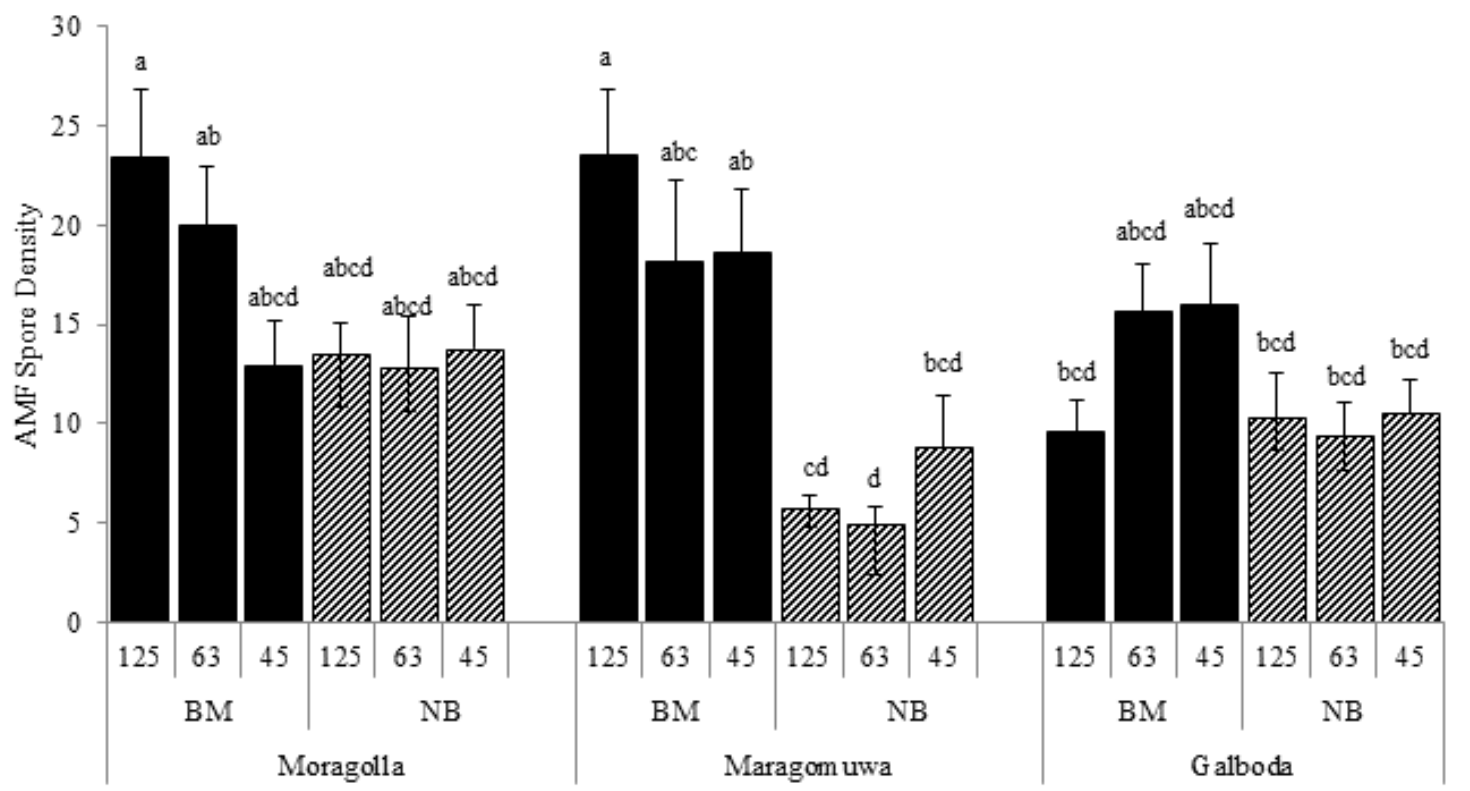

Figure 5: AMF spore density (per $100 \mathrm{~g}$ fresh soils) categorized into different size categories (125, 63 and $45 \mathrm{~m}$ ) in bamboo-dominated (BM) and non-bamboo (NB) forest patches in Moragolla, Maragomuwa and Galboda sites, Sri Lanka. Significant differences are indicated using different lowercase letters. Vertical bars indicate standard error of means (SEM). 
Table 3: Statistical parameters following the analysis of mean abundance and richness of AMF spores using General Linear Model (GLM). Significant differences between parameters and their interactions are indicated as '*' $\mathrm{p} \leq 0.05$, '**' $\mathrm{p} \leq 0.001$ and '***' $\mathrm{p} \leq$ 0.001 and 'ns' not significant.

\begin{tabular}{llll}
\hline \multicolumn{1}{c}{ Source of Variation } & DF & F value & \multicolumn{1}{c}{$\mathbf{P}$} \\
\hline Site $(\mathrm{MOR} / \mathrm{MAR} / \mathrm{GAL})$ & 2 & 4.23 & $0.016^{*}$ \\
Dominance $(\mathrm{BM} / \mathrm{NB})$ & 1 & 40.13 & $0.000^{* * *}$ \\
Spore size $(45 / 63 / 125 \mu \mathrm{m})$ & 2 & 0.24 & $0.787^{\mathrm{ns}}$ \\
Site $\times$ Dominance & 2 & 6.57 & $0.002^{* *}$ \\
Site $\times$ Spore Size & 4 & 1.77 & $0.138^{\mathrm{ns}}$ \\
Dominance $\times$ Spore Size & 2 & 1.33 & $0.268^{\mathrm{ns}}$ \\
Site $\times$ Dominance $\times$ Spore size & 4 & 1.77 & $0.137^{\mathrm{ns}}$ \\
\hline
\end{tabular}
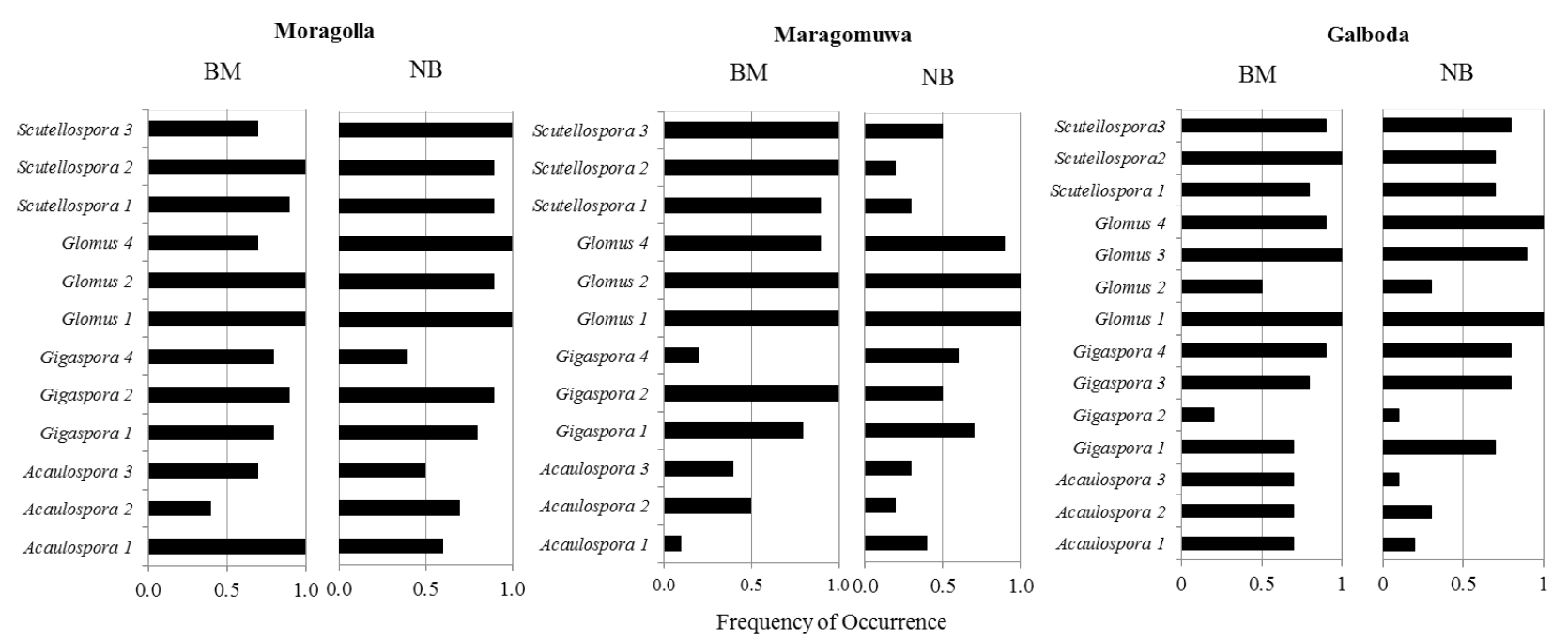

Figure 6: Frequency of occurrence of different AMF spore morphotypes belonging to Acaulospora (3 species), Gigaspora (4 species), Glomus (4 species) and Scutellospora (3 species) in bamboo-dominated (BM) and non-bamboo (NB) forest patches at Moragolla, Maragomuwa and Galboda sites.

At Maragomuwa, the densities of AMF spores belonging to large and medium size categories (125 and $63 \mu \mathrm{m})$ were significantly lower in NB than that in BM (Figure 5 and Table 3). The frequency of occurrence of AMF morphotypes was rather similar between BM and NB forest patches at Moragolla, but more distinct differences were recorded in Maragomuwa. The Acaulospora and Scutellospora spores were more frequent in BM than in $\mathrm{NB}$ at Galboda and Maragomuwa, respectively. Also, one Gigasporasp. (Gigaspora 3) was recorded exclusively in both BM and NB forest patches at Galboda, while all other morphotypes shared among sites (Figure 6).

\section{DISCUSSION}

Any modifications to the above-ground vegetation may impose significant impacts on the soil microbiota due to their high inter-dependence (Hooper et al., 2000). A preliminary vegetation survey has shown that the overdominance of $B$. bambos has incurred compositional changes in TMEF forests in Sri Lanka (Wijewickrama et $a l ., 2017)$. The results of the present study showed that the over-abundance of $B$. bambos has increased the abundance and richness of AMF spores, with few site-specific contrasts possibly due to inherent differences in terms of vegetation, edaphic parameters and on-going disturbances (natural and anthropogenic) between study sites. Previous studies have also demonstrated that the abundance and diversity of soil microbes could increase following invasion of exotic bamboos despite the reduced plant diversity in native forests in China (Xu et al., 2015; Qin et al., 2017). In contrast, Li et al., (2017) observed a reduced abundance and modified community composition in fungi following a bamboo invasion, discouraging generalization of potential impacts. Though some AMF are known to be host specific (Alguacil et al., 2011; Martinez-Garcia et al., 2015), few species have the ability to colonize wide range of host species (ÖPik et al., 2006). This explains how aboveand below-ground communities may alter according to the 'Driver/Passenger Hypothesis', with plants driving AMF communities and vice versa (Hart et al., 2001). Furthermore, other environmental and soil factors may also contribute to any changes in AMF communities (Xu et al., 2015; Li et al., 2017). Soil pH has been identified as one of the crucial parameters responsible for changes in plant and AMF communities (Helgason and Fitter, 2009). Increase of soil $\mathrm{pH}$ following bamboo invasion has been reported by many workers (Chang and Chiu, 2015; Umemura and Takenaka, 2015; Pan et al., 2015).In the 
present study too, though not significantly always, BM patches had relatively higher $\mathrm{pH}$ compared to that of $\mathrm{NB}$, further confirming the link between soil $\mathrm{pH}$ and AMF. In addition, other abiotic factors such as available $\mathrm{N}$ and $\mathrm{P}$, soil organic matter, soil moisture and temperature may also responsible for changes in AMF communities, though the parameters are not analyzed in the present study (Li et al., 2015; Hazard et al., 2013; Qin et al., 2015; Qin et al., 2017; Sun et al., 2013).

The present study has recorded relatively low AMF spore densities (19 - 60 AMF spores per $100 \mathrm{~g}$ soil) in contrast to numbers obtained in different forest types in other regional countries including Sri Lanka (Mafaziya and Madawala, 2015; Madawala, 2014; Chandrasekera et al., 2005; Jefwa et al., 2009; Belay et al., 2015). The lower numbers in the present study may perhaps due to low sporulation events during the time of the sampling. Edaphic and environmental properties, together with the different vegetation and natural and anthropogenic disturbances may also have contributed to relatively low spore counts (Mafaziya and Madawala, 2015). The AMF spore abundance shows an inverse relationship with that of the soil moisture (Shukla et al., 2013; Bouamri et al., 2014). In the present study, the soil samples were collected at the end of a wet period, perhaps explaining the low numbers of AMF spores.

The results suggest that the over-abundance of $B$. bambos did not change the composition and structure of AMF communities, reiterating the resilience of AMF communities to disturbances (Urcelay et al., 2009; Xiang et al., 2015). In the present study, the genus Glomus represented approximately $50 \%$ of the total AMF spores in all study sites, irrespective of the dominance of B. bambos. Glomus and Acaulospora species usually produce more spores than that of Gigaspora and Scutellospora (Holste et al., 2016), thus favouring the fact that smaller spores are faster in production than that of larger spores (Hepper, 1984). Glomus is also a known host generalist, with the potential to colonize a range of plants (Börstler et al., 2008). Moreover, Glomusis better adapted to disturbances due to their high sporulation rates and colonizing potentials (Daniell et al., 2001). Others suggest that Glomus can be more dominant in high organic soils (Lekberg et al., 2007), while Gigaspora and Scutellospora with extensive extraradical hyphal growth and nutrient acquisition power may favour low fertile soils (Hart and Reader, 2002; Maherali and Klironomos, 2007). However, with the ability to produce relatively smaller spores, Acaulospora still showed the least dominance in all study sites in the present study.

The results suggest that the $30-40$ years of overabundance of $B$. bambos (based on the communications from the villagers in peripheral hamlets) has shown the potential to increase the mean abundance and richness of AMF but with no compositional modifications in their AMF communities. However, previous studies have demonstrated compositional changes in AMF communities following invasion by exotic species (Yang et al., 2016) while others reiterated their resilience to such disturbances
(Carey et al., 2015). These conflicting findings may perhaps due to the ability of AMF communities to revert back to their initial state so rapidly following immediate responses to changes in vegetation (Lankau, 2011; Carey et al., 2015). Studies also revealed that seasonal and/or annual compositional changes could also be observed in AMF communities due to changes in biotic and abiotic factors (Docherty et al., 2012; Frenk et al., 2014). In the present study, the soils were sampled only once, thus making difficult to capture any seasonal/annual changes to composition of the AMF communities.

\section{CONCLUSION}

The results show the potential of increasing the abundance and sometimes even richness of AMF following the dominance of B. bambos. However, the AMF community structure seems unaffected indicating their resilience to above-ground changes. In order to capture seasonal changes of AMF communities, more frequent and intense sampling is recommended.

\section{ACKNOWLEDGEMENTS}

The authors wish to acknowledge the financial assistance provided by the National Research Council of Sri Lanka (Project No: 16-054).

\section{REFERENCES}

Alguacil M.M., Torres, M.P., Torrecillas, E., Diaz, G. and Roldan, A. (2011). Plant type differently promote the arbuscular mycorrhizal fungi biodiversity in the rhizosphere after revegetation of a degraded, semiarid land. Soil Biology and Biochemistry 43: 167-173.

Bouamri R., Dalpe, Y. and M.N. Serrhini (2014). Effect of seasonal variation on arbuscular mycorrhizal fungi associated with date palm. Emirates Journal of Food and Agriculture 26(11): 977-986.

Börstler, B., Raab, P.A., Thiery, O., Morton, J.B. and Redecker D. (2008). Genetic diversity of the arbuscular mycorrhizal fungus Glomus intraradices as determined by mitochondrial large subunit rRNA gene sequences is considerably higher than previously expected. New Phytologist 180(2): 452-265.

Bai, S.B., Zhou, G.M., Wang, Y.X., Liang, Q.Q., Chen, J., Cheng, Y.Y. and Shen, R. (2013). Plant species diversity and dynamicsin forests invaded by Moso bamboo (Phyllostachy edulis) in Tianmu Mountain nature Reserve. Biodivers Sci 21: 288-295.

Belay, Z., Vestberg, M. and Assefa, F. (2015). Diversity and abundance of arbuscular mycorrhizal fungi across different land use types in humid lowland area of Ethiopia. Tropical and Subtropical Agroecosystems 18: 47-69.

Chang, E.H. and Chiu, C.Y. (2015). Changes in soil microbial community structure and activity in a cedar plantation invaded by moso bamboo. Applied Soil Ecology 91: 1-7.

Carey C.J., Beman J.M., Eviner V.T., Malmstrom C.M. and Hart S.C. (2015). Soil microbial community structure is unaltered by plant invasion, vegetation clipping, 
and nitrogen fertilization in experimental semi-arid grasslands. Frontiers in Microbiology 6: 466. doi: 10.3389/fmicb.2015.00466

Chandrasekera, C.M.C.P., Madawala, H.M.S.P., Gunatilleke I.A.U.N. and Seneviratne, G. (2005). Spatial distribution of arbuscular mycorrhizas along an elevation and edaphic gradient in the forest dynamic plot at Sinharaja, Sri Lanka. Ceylon Journal of Sciences (Biological Sciences) 34: 47-68.

Daniell, T.J., Husband, R., Fitter A.H. and Young J.P.W. (2001). Molecular diversity of arbuscular mycorrhizal fungi colonizing arable crops. FEMS Microbiology Ecology 36: 203-209.

Docherty, K. M., Balser, T.C., and Bohannan, B. (2012). Soil microbial responses to fire and interacting global change factors in a California annual grassland. Biogeochemistry 109: 63-83. doi: 10.1007/s10533-0119654-3

Edirisinghe C. and Madawala H.M.S.P. (2017). Arbuscular mycorrhizal fungal dynamics following change of land use from mature forest to Eucalyptus plantation. Journal of National Science Foundation Sri Lanka 45(4): 321-328

Ehrenfeld, J. G. (2010). Ecosystem consequences of biological invasions. Annual Review of Ecology, Evolution and Systematics. 41: 59-80.

Frenk, S., Hadar, Y., and Minz, D. (2014). Resilience of soil bacterial community to irrigation with water of different qualities under Mediterranean climate. Environmental Microbiology 16: 559-569. doi: 10.1111/14622920.12183

Grayston, S.J., Campbell, C.D., Bardgett, R.D., Mawdsley, J.L., Clegg, C.D., Ritz, K., Griffith, B.S., Rodwelld, J.S., Edwards, S.J., Davies, W.J., Elstone, D.J. and Millard, P. (2004). Assessing shifts in microbial community structure across a range of grasslands of differing management intensity using CLPP, PLFA and community DNA techniques. Applied Soil Ecology 25: 63-84.

Holste, E.K., Holl, K.D., Zahawi, R.A. and Kobe, R.K. (2016). Reduced aboveground tree growth associated with higher arbuscular mycorrhizal fungal diversity in tropical forest restoration. Ecology and Evolution 6:7253-7262.

Gunatilleke, N., Pethiyagoda, R. and Gunatilleke, S. (2008). Biodiversity of Sri Lanka. Journal of the National Science Foundation of Sri Lanka 36: 25-62

Hart, M.M. and Reader, R.J. (2002). Does percent root length colonization and soil hyphal length reflect the extent of colonization for all AMF? Mycorrhiza 12: 297-301.

Hart M.M., Reader R.J., Klironomos J.N. (2001). Lifehistory strategies of arbuscular mycorrhizal fungi in relation to their successional dynamics. Mycologia 93: 1186-1194.

Helgason, T. and Fitter, A.H. (2009). Natural selection and the evolutionary ecology of the arbuscular mycorrhizal fungi (phylum Glomeromycota). Journal of Experimental Botany 60: 2465-2480.

Hepper C.M. (1984). Regulation of spore germination of the vesicular-arbuscular mycorrhizal fungus
Acaulosporaleavis by soil pH.Transactions of the British Mycological Society 83: 154-156.

Hazard, C., Gosling, P., van der Gast, C.J., Mitchell, D.T., Doohan, F.M. and Bending, G.D. (2013). The role of local environment and geographical distance in determining community composition of arbuscular mycorrhizal fungi at the landscape level. The ISME Journal 7: 498-508.

Hooper, D.U., Bignell, D.E., Brown, V.K., Brussard, L., Dangerfield, M.J., Wall, D.H., Wardle, D.A., Coleman, D.C., Giller, K.E., Lavelle, P., Van Der Putten, D.H., De Ruiter, P.C., Rusek, J., Silver, W.L., Tiedje, J.M. and Wolters, V. (2000). Interactions between Aboveground and Belowground Biodiversity in Terrestrial Ecosystems: Patterns, Mechanisms, and Feedbacks: We assess the evidence for correlation between aboveground and belowground diversity and conclude that a variety of mechanisms could lead to positive, negative, or no relationship - depending on the strength and type of interactions among species. BioScience 50(12): 1049-1061.

Jefwa, J.M., Mung'atu, J., Okoth, P., Muya, E., Roimen, H. and Njuguini, S. (2009). Influence of landuse types on occurrence of arbuscular mycorrhizal fungi in the high altitude regions of Mt. Kenya. Tropical and Subtropical Agroecosystems 11: 277-290.

Lankau, R. A. (2011). Resistance and recovery of soil microbial communities in the face of Alliariapetiolata invasions. New Phytologist 189: 536-548.

Larpkern P., Moe S.R., Totland Ø. (2011). Bamboo dominance reduces tree regeneration in a disturbed tropical forest. Oecologia 165: 161-168.

Lekberg, Y., Koide, R.T., Rohr, J.R., Aldrich-Wolfe, L. and Morton, J.B. (2007). Role of niche restrictions and dispersal in the composition of arbuscular mycorrhizal fungal communities. Journal of Ecology 95: 95-100.

Lin, Y.T., Tang, S.L., Pai C.W., Whitman, W.B., Coleman, D.C., Chiu, C.Y. (2014). Changes in soil bacterial communities in a cedar plantation invaded by Moso bamboo. Microbial Ecology 67: 421-429.

Li, X., Zhang, J., Gai, J., Cai, X., Christie, P. and Li, X. (2015). Contribution of arbuscular mycorrhizal fungi of sedges to soil aggregation along an altitudinal alpine grassland gradient on the Tinetan plateau. Environment and Microbiology 17: 2841-2857.

Li, Y., Li, Y., Chang, S.X., Xu, Q., Guo, Z., Gao, Q., Qin, Z., Yang, Y., Chen, J. and Liang, X. (2017). Bamboo invasion of broadleaf forests altered soil fungal community closely linked to changes in soil organic $\mathrm{C}$ chemical composition and mineral N production. Plant and Soil. DOI: 10.1007/s11104-017-3313y.

Martinez-Garcia, L.B., Richardson, S.J., Tylianakis, J.M., Peltzer, D.A. and Dickie, I.A. (2015). Host identity is a dominant driver of mycorrhizal fungal community composition during ecosystem development. New Phytologist 205: 1565-1576.

McDowell, N.G and Allen, C.A. (2015). Darcy's law predicts widespread forest mortality under climate warming. Nature Climate Change 5: 669-672.

Maherali, H. andKlironomos, J.N. (2007). Influence of phylogeny on fungal community assembly and 
ecosystem functioning. Science 316: 1746-1748.

Mafaziya, F. and Madawala H.M.S.P. (2015). Abundance, richness and root colonization of arbuscular mycorrhizal fungi in natural and semi-natural landuse types at Upper Hantana. Ceylon Journal of Science (Biological Sciences) 44(1): 25-34.

Madawala, H.M.S.P. (2014). Austroeupatorium inulifolium invasion increase arbuscular mycorrhizal abundance in Cymbopogon-dominated grasslands in Knuckles Conservation Area. Journal of National Science Foundation 42(4):405-408.

Öpik , M., Moora, M., Liira, J. and Zobel, M. (2006). Composition of root colonizing arbuscular mycorrhizal fungal communities in different ecosystems around the globe. Journal of Ecology 94: 778-790.

Pan, L., Mo, P., Bai, S.B. and Gu, M. (2015). Impact of Phyllostachysheterocycla 'Pubescens' expansion on mycorrhizal associations of the adjacent forests. Chinese Journal of Plant Ecology 39: 371- 382.

Peay, K.G., Baraloto, C. and Fine, P.V. (2013). Strong coupling of plant and fungal communitt structure across western Amazonian rainforests. ISME Journal 7: 18521861.

Qin, H., Niu, L., Wu, Q., Chen, J., Li, Y., Liang, C., Xu, Q., Fuhrmann, J.J. and Shen, Y. (2017). Bamboo forest expansion increases soil organic matter through its effect on soil arbuscular mycorrhizal fungal community and abundance. Plant and Soil DOI: 10.1007/s111104017-3415-6.

Qin, H., Lu, K., Strong P.J., Xu Q., Wu Q., Xu, J. and Wang H. (2015). Long-term fertilizer application effects on the soil, root arbuscular mycorrhizal fungi and community composition in rotation agriculture. Applied Soil Ecology 89: 35-43.

Rodrigues R.R., Pineda R.P., Barney J.N., Nilsen E.T., Barrett, J.E. and Williams M.A. (2015). Plant invasions associated with change in root-zone microbial community structure and diversity. PLOS ONE 10(10): e0141424.doi:10.137/journal.pone.0141424.

Somasekeram, T., Perera , L.A.G., Perera, M.P., De Silva, B.G., Karunanayake, M.M, and Epitawatta, D.S., (1988). National Atlas, Survey Department, Colombo.

Sharma, M.P. and Buyer, J.S. (2015). Comparison of biochemical and microscopic methods for quantification of arbuscular mycorrhizal fungi in soils and roots. Applied Soil Ecology 95: 86-89.

Shukla, A., Vyas, D. and Jha, A. (2013). Soil depth: an overriding factor for distribution of arbuscular mycorrhizal fungi. Journal of Soil Science and Plant Nutrition 13(1): 23-33.

Sieverding, E. (1991). Vesicular-arbuscular mycorrhiza management in Tropical agrosystems. GTZ, Eschborn, Germany. $371 \mathrm{p}$.

Sun, X.F., Su, Y.Y., Zhang, Y., Wu, M.Y., Zhang, Z., Pei, K.Q., Sun, L.F., Wan, S.Q. and Liang, Y. (2013). Diversity of arbuscular mycorrhizal fungal spore communities and its relations to plants under increased temperature and precipitation in a natural grassland. Chinese Science Bulletin 58(33): 4109-4119.

Umemura M. and Takenaka C. (2015). Changes in chemical characteristics of surface soils in hinoki cypress (Chamaecyparis abtusa) forests induced by the invasion of exotic moso bamboo (Phyllostachys pubescens) in Central Japan. Plant Species Biology 30: 72-79.

Urcelay, C., D1'az, S., Gurvich, D.E., Chapin, F.S., Cuevas, E., and Domı'nguez, L.S. (2009). Mycorrhizal community resilience in response to experimental plant functional type removals in a woody ecosystem. Journal of Ecology 97: 1291-1301.

Vila M., Espinar J.L., Hejda M., Hulme P.E., Jarosik V., Maron J.L. et al. (2011). Ecological impacts of invasive alien plants: a meta-analysis of their effects on species, communities and ecosystems. Ecology Letters 14: 702708.

Wijewickrama, M.P.T., Wijesundara, D.S.A. and Madawala H.M.S.P. (2017). Impacts of Bambusabambos (L.) Voss. onflosirstic composition and tree mortality in a tropical moist semi-evergreen forest in Sri Lanka. Proceedings of the iPURSE, University of Peradeniya.

Willis, A., Sparks, T.H., Rodrigues, B.F. and Harris P.J.C. (2016). Organic amendment increases arbuscular mycorrhizal fungal diversity in primary coastal dunes. European Journal of Ecology 2(2): 1-8.

Xiang, X., Gibbons, S.M., Yang, J., Kong, J., Sun, R. and Chu, H. (2015). Arbuscular mycorrhizal fungal communities show low resistance and high resilience to wildfire disturbance. Plant and Soil 397(1-2): $347-$ 356.

Xu, Q.F., Jiang P.K., Wu J.S., Zhou G.M., Shen R.F., Fuhmann J.J. (2015). Bamboo invasion of native broadleaf forest modified soil microbial communities and diversity. Biological Invasions 17: 433-444.

Yang, W., Jeelani, N., Leng, X., Cheng, X. and An, S. (2016). Spartinaalterniflora invasion alters soil microbial community composition and microbial respiration following invasion chronosequence in a coastal wetland of China. Scientific Reports 6: 26880; doi: 10.1038/srep26880.

Zhang, Q., Yang R., Tang J., Yang H., Hu S. and Chen X. (2010). Positive feedback between mycorrhizal fungi and plants influences plant invasion success and resistance to invasion. PLOS ONE 5: e12380.

Zhang, T., Yang, M., Guo, R. and Guo J. (2016). Response of AM fungi spore population to elevated temperature and nitrogen addition and their influence on the plant community composition and productivity. Scientific Reports 6: 24749; doi: 10.1038/srep24749.

Zubek, S., Majewska M.I., Blaszowski J., Stefanowicz, A.M., Nobis, M. and Kapusta P. (2016). Invasive plants affect arbuscular mycorrhizal fungi abundance and species richness as well as the performance of native plants grown in invaded soils. Biological Fertility Soils 52: 879-893. 